the Netherlands was hosting the five-days' intergovernmental meeting, which was being held under the auspices of the Intergovernmental Panel on Climate Change (IPCC), which itself was established by WMO and UNEP in 1988 to assess and explore ways of furthering our understanding of the climate-change process.

The WMO Secretary-General also emphasized to participants that sea-level change could affect global shipping infrastructures, ports and harbours, and the world trade and communication that these sustained. In addition, sea-level change could have detrimental effects on the beautiful beaches and resorts which promote global tourism and generate revenues for many nations. He also pointed out that coastal zones and small-island states were prone to storm surges, which are usually caused by tropical cyclones, hurricanes, or typhoons. In turn, these surges cause severe flooding and in some cases inundate large areas of coastal lands, thus destroying lives and property. Rising sea-levels may exacerbate these extreme events.

Rising tides and storm surges, coupled with floods from rivers, will also cause water-quality problems for coastal areas. The solution, according to Professor Obasi, is being constrained by the lack of sufficient observations of surface water and river flows. In many parts of the world, especially in the developing countries, measurements of river flows are lacking, and where they exist, networks of stations are often inadequate at best.

It is for this reason that WMO is promoting, with the support of the World Bank, UNESCO, and others, the concept of a World Hydrological Cycle Observing System (WHYCOS). Using existing WMO systems, such as the World Weather Watch and the Hydrology and Water Resources Programme, WHYCOS aims at providing timely observations of discharge and water quality from the major rivers of the world, together with associated observations of weather and climate. WHYCOS is expected to create a reliable global water resources archive which would make the data available for sound coastal-zone management and for decision-making.
The Secretary-General described the various WMO programmes and endeavours that were being carried out, with other UN agencies and non-governmental organizations, related to the ocean and atmosphere - such as the World Ocean Circulation Experiment (WOCE) and the Tropical Oceans Global Atmosphere (TOGA) project. Many of the islands in the tropical Pacific have been equipped with tide-gauges through the TOGA project. The Global Ocean Observing System (GOOS) will ensure global, permanent, and systematic, observations that are essential for forecasting climate change and variability, and for assessing the health and state of the marine environment. GOOS will serve as the ocean component of the Global Climate Observing System (GCOS), another interagency effort which aims to reduce the uncertainties about climate change.

In view of the important interactions of the atmosphere with the world ocean, the role of the Global Atmosphere Watch (GAW) of WMO and its value in the monitoring and prediction of the chemical and biological exchanges within the atmosphere, were underlined, while in emphasizing the strengthening of national capacities for sustainable development, the WMO Secretary-General said that it is of vital importance that the existing national, regional, and global, scientific and technological capacities be strengthened for the monitoring, assessment, analysis, and prediction, of climate and environmental changes particularly in critically vulnerable regions such as small islands and low-lying coastal areas.'

The World Coast Conference was one of the first major conferences that are being held on all aspects of coastalzone management. A global conference on the Sustainable Development of Small-island Developing States will be convened by the United Nations in Barbados in April of 1994.

Information and Public AfFairs Office World Meteorological Organization PO Box 2300

1211 Geneva 2

Switzerland.

\title{
London Initiative on the Russian Environment
}

$\mathrm{F}_{\mathrm{n}}^{\mathrm{o}}$ ollowing a year of preparatory work, including meetings in four other countries, the London Initiative on the Russian Environment held its inaugural Steering Committee meeting at the Royal Geographical Society, London, early in December 1993, to consider future projects. The Committee developed follow-up points for action based upon a protocol signed by the Initiative's Russian delegation, headed by Russia's Deputy Minister for Environmental Protection and Natural Resources, Dr Amirkhan M. Amirkhanov, and the Conservation Foundation. The protocol outlined the possibility of investigations or collaboration on projects with a number of UK institutions and organizations which met with the Russian ministerial delegation, including:

- development of a programme to save the endangered Siberian Tiger (Felis tigris ssp.);

- a partnership with Imperial College, London, regarding solid waste;

- participation with British commercial partners in the World Bank's master plan for ecotourism in the Lake Baikal basin;

- the establishment of a common database on specific environmental issues and technical assistance from the World Conservation Monitoring Centre in Cambridge, England;

- cooperation with the Television Trust for the Environment, London, to provide environmental education tapes for Russian schoolchildren and students;

- possible cooperation between the protected area systems of Russia and the UK in support of the EECONET system; and

- examination of the possibility of twinning protected areas in Russia and the UK.

The London Initiative, presided over by Professor David Bellamy, is a new private-sector group developed to encourage and focus environmental expertise, aid, and investment, from Britain and other market-economy countries to help Russia to deal with its massive environmental needs. The organization aims to assist the Russian environment in six targeted areas: water quality, waste management, energy conservation, sustainable local development, protected areas, and environmental education. The Initiative was launched at a high-level reception in the Victoria \& Albert Museum, London, on 24 November 1993. 
More than 350 British and Russian government officials, representatives of various international organizations, distinguished members of the business community, and media leaders, attended the launch reception.

The concept of the London Initiative was developed by John Massey Stewart, an author and expert on Russia who has written on environmental issues facing Russian society, and was adopted by the Conservation Foundation. Over the past year, the Initiative has been gathering endorsements from a wide variety of national and international organizations, including the UN Environment Programme (UNEP). Currently the Conservation Foundation is aspiring to raise $\mathfrak{2} 200,000$ to run the Initiative and help specific projects in Russia. Support has already been received from a number of corporate sponsors, including Price Waterhouse, lead sponsor for the launch events, but much more is needed.

DAVID SHREEVE, Co-founder \& Executive Director
The Conservation Foundation
Kensington Gore
London $S W 72 A R$
England, UK.

Tel. (071) 823-8842

Fax (071) 823-8791

\section{Turning-point for South Africa's St Lucia Wetlands?}

$\mathrm{C}^{\mathrm{c}}$ ontroversy over the future of South Africa's St Lucia wetlands has moved a long step closer to resolution. This large complex of varied habitat types and great biological diversity occupies over 250,000 hectares along the east coast of Natal province. Some 155,000 hectares of the system were designated for the Ramsar List of Wetlands of International Importance in 1986.

Leases for the open-dredge mining of heavy-metals, especially titanium, in the dune areas along the eastern shore of Lake St Lucia have raised the hope of new jobs for the region in the short term but brought the likelihood of serious environmental damage to the entire system. The Conference of the Contracting Parties to the Ramsar Convention expressed its concern in 1990 and 1993, calling upon South Africa to retain the site's protected status. In 1992, a Ramsar Monitoring Procedure team studied the site and presented a detailed report, which recommended that the authorities consider whether, in the light of their nation's obligations under the Convention, the application to exercise mining rights should not be refused. An Environmental Impact Assessment (EIA) was performed which failed to find reason to fear serious damage from the proposed mining in the sensitive dune areas; however, this report was quickly challenged by concerned conservation organizations.

The Government then appointed an independent fivemembers' Review Panel of experts to study the reports and make recommendations to guide its decision, and on 10 December 1993 the Panel issued its conclusions. The Panel contradicts the EIA and recommends that 'no mining should be allowed in the Greater St Lucia area'; it maintains that mining 'would cause unacceptable damage to a place which is special' - one for which 'there is no substitute.' Instead, the Panel urges that the site be given World Heritage status and that its potential for ecotourism be developed for the economic benefit of the local population and as 'a very special asset of the nation.'

The Ramsar Convention Bureau welcomes the Panel's report enthusiastically. Secretary-General Daniel Navid has congratulated the South African Government for 'sending a strong signal to other governments throughout southern Africa; its example, backed by the expertise of its specialists, will allow it to play a leading role in the conservation and wise use of wetlands of the region.' Michael Smart, Assistant Secretary-General, said that the Bureau particularly appreciates the Review Panel's emphasis on 'the urgency of resolving the situation of local people, a concern entirely in line with the Ramsar concept of "wise use" of wetlands.'

The 'Convention on Wetlands of International Importance, especially as Waterfowl Habitat', adopted at Ramsar, Iran, in 1971, provides the framework for international cooperation for the conservation of wetland habitats. It now has 80 member states, and there are 644 wetlands around the world included in the Ramsar List.

Mirellle Katz, Communications Officer
Ramsar Convention Bureau
Rue Mauverney 28
I196 Gland
Switzerland.
Ramsar Convention Bureau

1196 Gland

Switzerland.

\section{Trapnell Fund for Environmental Field Research in Africa}

$\mathrm{T}$ he University of Oxford invites applications for support from the above for field-based research concerned with the African environment. Proposals involving research into the ecological aspects either of soils or of indigenous forests and woodland in the tropical region of Africa may be given preference. Applicants should be graduates of British or African universities who are, or will be, working for a research degree of the University of Oxford or who hold a post-doctoral position at Oxford.

Subject to the availability of funds, the awards made may range from grants for field-work expenses to full postgraduate scholarships. Applications for which partial support has already been raised will be particularly wel- come. Awards will be available from 1 October 1994. The closing date for receipt of applications is 1 March 1994.

Further particulars may be obtained from the undersigned to whom applications should be sent - or from Dr P.S. Savill, Department of Plant Sciences, South Parks Road, Oxford OX1 3RA, England, UK.

MRS JUDITH M. BROWN
University Offices
Wellington Square
Oxford OXI 2JD
England, UK.
$\quad$ Tel. (0044865) 270708
$\quad$ Fax (0044865) 270708.

